\title{
Review on the distribution of microplastics in the oceans and its impacts: Need for modeling-based approach to investigate the transport and risk of microplastic pollution
}

\author{
A. Merline Sheela ${ }^{\dagger}$, B. Manimekalai, G. Dhinagaran \\ Centre for Environmental Studies, Anna University, Chennai, Tamil Nadu - 600 025, India
}

\begin{abstract}
Many studies have proven that microplastics are transported from the terrestrial ecosystem to the marine ecosystem. Furthermore, it has been established that a significant quantity is added to the marine ecosystem through river transport and atmospheric deposition. Though several methods exist to estimate the concentration of microplastics in the marine ecosystem, it is very difficult to precisely quantify the pollutants and determine the amount transported from the land to the ocean. The data on the extent of microplastic pollution are influenced by the sampling methods and the time of sampling. An examination of the literature reveals that only limited studies have been conducted to examine the interaction of microplastics and their additives with the marine organisms. Hence, more such studies are warranted to shed light on these interactions. Few modeling studies have been conducted to estimate the future addition of plastics to the marine ecosystem. To obtain better output, appropriate models that consider the current scenario need to be developed. Models help us to understand the sources, transport, sinks, and risks of microplastic pollution. This will enable us to develop appropriate strategies and, measures to reduce plastic littering in the environment, thus marine plastic pollution is minimized in the future.
\end{abstract}

Keywords: Marine Ecosystem, Microplastics, Modeling-based risk assessment

\section{Introduction}

The usage of plastics in our day-to-day life is increasing owing to their wide applicability in food packaging to toiletries, furniture, and recreational items. As of 2015, the global annual plastic production was 322 million tons [1]. Among the various sectors, packaging industry generates the highest amount of plastic wastes. The need for plastics in our daily life and the risks related to the improper disposal of plastic waste are illustrated in Fig. 1.

The monomers such as ethylene and propylene used for plastic production are obtained from hydrocarbons [2]. Around 14\% (by mass) of the plastic waste generated in 2013 was recycled, and the remaining was either recklessly disposed in the environment or landfilled [3]. It is anticipated that by 2050, an extra 33 billion tons of plastics will be added to the planet [4]. It has been observed that a significant amount of the mismanaged plastic waste from the coastal cities enters the rivers, lakes, and oceans, where the larger pieces are eventually broken down into smaller pieces called

This is an Open Access article distributed under the terms of the Creative Commons Attribution Non-Commercial License (http://creativecommons.org/licenses/by-nc/3.0/) which permits unrestricted non-commercial use, distribution, and reproduction in any medium, provided the original work is properly cited.

Copyright (C) 2022 Korean Society of Environmental Engineers microplastics. The microplastics are distributed across the ocean waters, seabed, sediments, coastlines, and beaches [5]. Microplastics are available in different forms such as spheres, fragments, and fibers, which in turn are converted to smaller debris called nanoplastics $(<1 \mu \mathrm{m})[6,7]$. Fragmentation of the microplastics in spherical forms could increase number of nanoparticles by $>10^{14}$ times [8]. It has been estimated that about 8 million tons of plastic waste are transferred from the land to the ocean each year [9]. From the land, the plastic litter enters the ocean via the rivers [10]. Beaches and agricultural runoff constitute the other land-based sources [11]. In addition, atmospheric deposition is another source of microplastic pollution to the oceans $[12,13]$. Few studies mentioned that poorly treated wastewater containing plastic debris is entry route for plastic litter into the oceans $[14,15]$. It has also been reported that high quantities of plastic debris are dispersed in remote or secluded zones such as the Polar Regions [16, 17] and deep oceans [18].

In general, beaches adjacent to the river mouth harbor more plastic debris [19]. Ships, platforms, and fishing spots are important
Received May 18, 2021 Accepted July 27, 2021
${ }^{\dagger}$ Corresponding author
E-mail: merlinshasu@gmail.com
Tel: +919884216255
ORCID: 0000-0002-4674-588X 
sea-based sources [20]. The accumulation of plastic wastes near the shores of Bay of Bengal where fishing harbor is established is illustrated in Fig. 2. The global plastic waste generation and the transport of mismanaged waste in the oceans are illustrated in Fig. 3. From the entry point, the ocean currents transport the

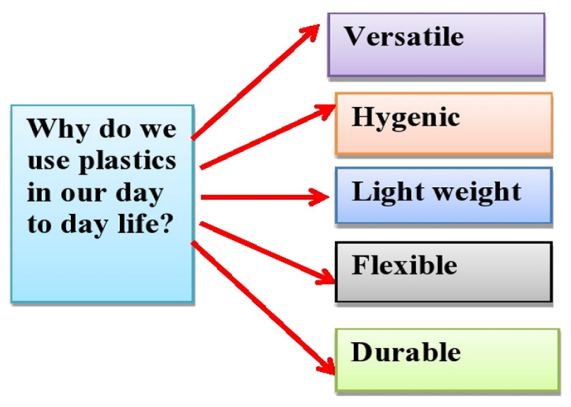

\begin{tabular}{|l|l|l|l|}
\hline \multicolumn{3}{|c|}{ Improper plastic waste disposal or management leads to } \\
\hline $\begin{array}{l}\text { Unhygienic } \\
\text { condition }\end{array}$ & $\begin{array}{l}\text { Soil } \\
\text { health } \\
\text { risk }\end{array}$ & $\begin{array}{l}\text { Drainage } \\
\text { blocking }\end{array}$ & $\begin{array}{l}\text { Risk on } \\
\text { aquatic } \\
\text { organisms }\end{array}$ \\
\hline
\end{tabular}

Fig. 1. Illustration showing uses of plastic and risks of improper disposal of plastic waste into the environment.

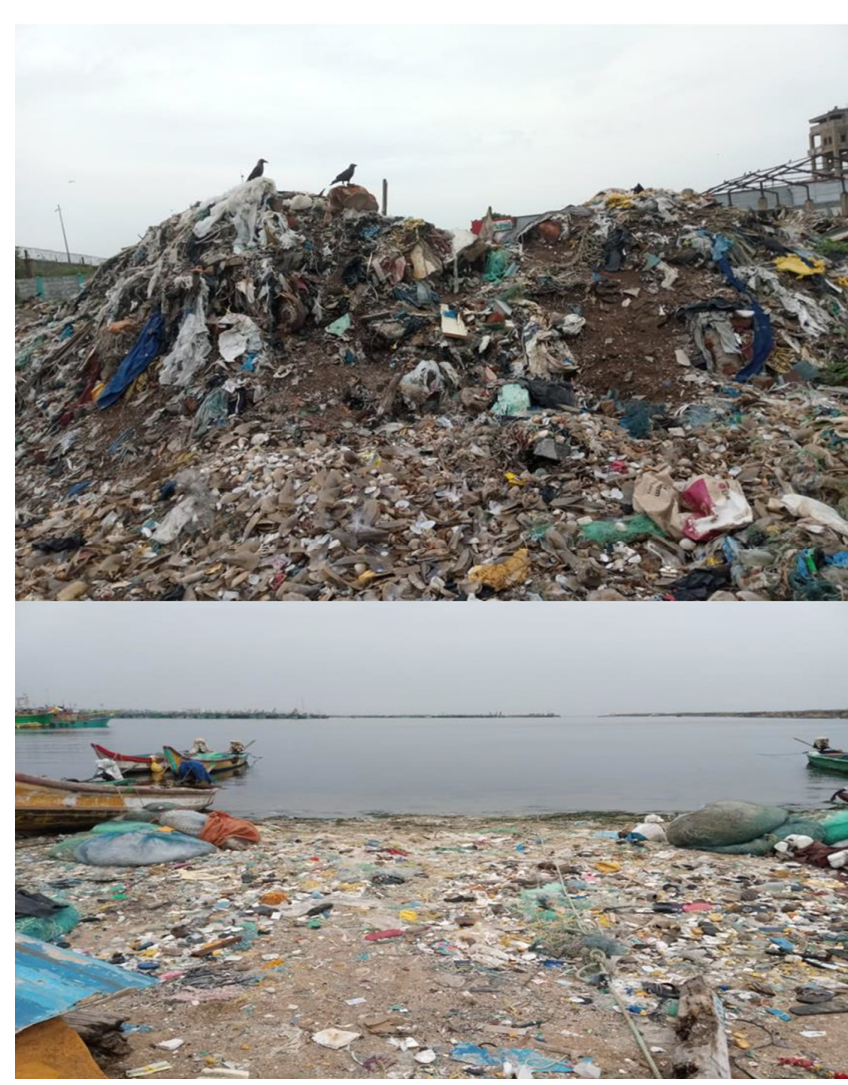

Fig. 2. Plastic waste accumulation on the shores of Bay of Bengal (photographed on January 20, 2020). The photograph was taken from a region where fishing harbor is located.

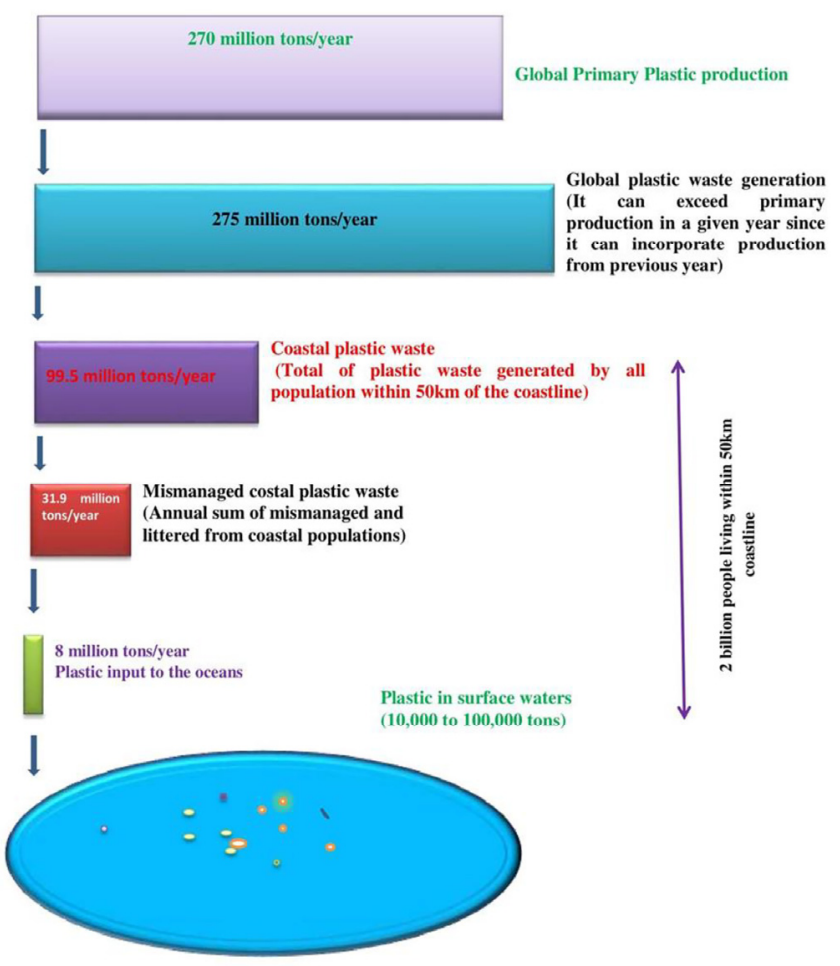

Fig. 3. Illustration showing Global primary plastic production, and entry of mismanaged plastic waste into the Ocean [9].

plastic wastes thousands of kilometers, thereby disseminating the pollutants [21]. The near-shore waters harbor more microplastics than the interior depths of the oceans. In recent years, microplastics have accumulated in the ocean waters and sediments worldwide, reaching a concentration of 10,000 particles $/ \mathrm{m}^{3}$ [22]. The marine organisms are endangered by the plastic wastes floating on the ocean surface [23]. Studies quantifying the abundance and weight of plastic debris floating on the ocean waters are limited, particularly for the Southern hemisphere and remote regions [24, 25]. Owing to the accumulation of plastics in the oceans, several harmful effects such as loss of aesthetics, increased cost involved in beach cleaning, and adverse effect on biological and ecological entities have been documented [26]. The overall economic damage due to plastic pollution in the marine ecosystem according to the last conservative estimates of the United Nations Environment Program (UNEP) was \$13 billion each year (UNEP Year Book and Valuing Plastic Nairobi, 2014).

Few studies have been conducted to know the medium of transport of microplastics to the marine environment. In addition, limited studies have been conducted to explain the interaction of microplastics with marine organisms. It is observed that developing suitable models to explain the sources, transport and risk of microplastic pollution in marine environment is needed. Hence, this review has the following objectives with regard to the research done in the field so far: (1) distribution of microplastics in the oceans, including the coral islands; (2) interaction of microplastics with marine organisms; (3) effect of plastic additives on marine organisms; and (3) the application of modeling-based approach 
to assess the transport and impact of microplastics on the marine organisms. The overall objective is to find the research gaps and emphasize more research to mitigate the risks due to plastic pollution in marine environment.

\section{Transport and Distribution of Microplastics in the Oceans}

\subsection{Sources}

Microplastics originate from different sources, namely point and diffuse sources. The important constraint encountered in research on microplastic pollution is the lack of quantitative data and the knowledge gap regarding the characteristics of the sources [27]. Studies have been conducted on the distribution of plastic debris in the environment [28-30] and the effect of plastic pollution on the marine organisms [31]. Furthermore, the percapita consumption of plastics by different sectors has been reported [32]. The microplastic content in the incoming water to the sewage [33, 34] and domestic water [35] treatment plants has also been documented. However, sufficient data are not available on the quantity of plastic debris transported from various sources to the marine environment.

\subsection{Distribution in the Oceans}

The microplastic distribution in the five oceans, namely the Pacific, Atlantic, Indian, Antarctic, and the Arctic Ocean has been reviewed and summarized. Furthermore, details of the sampling methods adopted as well as the quantity and types of microplastics examined have been furnished (Table 1).

The number of studies conducted so far to investigate the microplastics in the Pacific, Atlantic, Indian, Antarctic, and Arctic Ocean from 2013 to 2020 were 6, 5, 2, 3 and 2, respectively (Fig. 4(a)). The studies are not enough to investigate the appropriate quantity of microplastics in the oceans.

\subsection{Distribution of in the Coral Islands}

The development of coral reef islands occurs when favorable conditions, namely physical (high temperature, high salinity, appropriate light penetration, and low nutrition) and biological factors (the supply of coral larvae), are present [53]. In general, microplastics interact with the corals by active ingestion and passive surface adhesion. The ingestion of microplastics by the corals affects their physiology, energetics, growth, and development [54]. Only few studies have been conducted to investigate the presence and effects of microplastics on the corals. Microplastic ingestion by the Scleractinian corals and the occurrence of microplastics in coral reef waters adjacent to inshore reefs in Australia's Great Barrier Reef has been explored by Hall et al [55]. Corals in three atolls from the Xisha Islands of the South China Sea were found to contain microplastics. Microplastics were detected in the outer reef slopes (0.2-11.2 items/L), reef flats (1.0-12.2 items/L), and lagoons (1.0-45.2 items/L). The detected microplastics were predominantly fibrous rayon and polyethylene terephthalate (PET) [56]. Moreover, $96 \pm 51$ items/L and $259 \pm 88$ items $/ \mathrm{kg}$ were found in the water and sediment samples collected from Rameshwaram

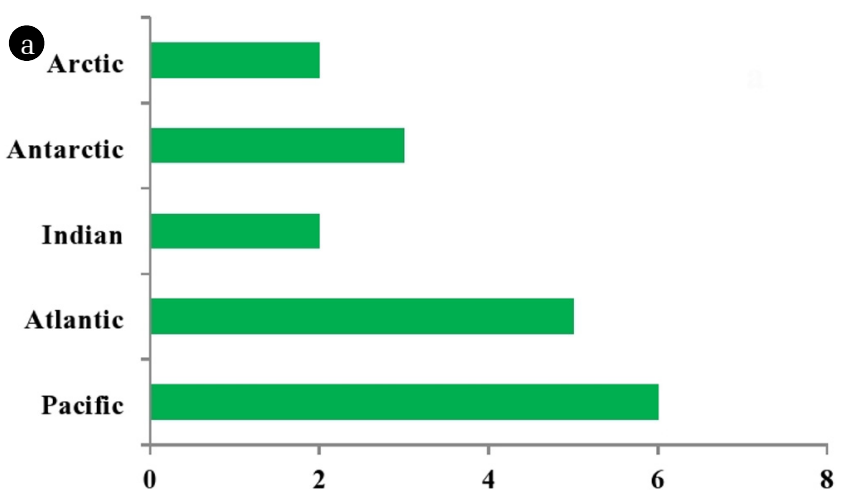

Number of studies to assess the distribution of microplastics (2013-2020)

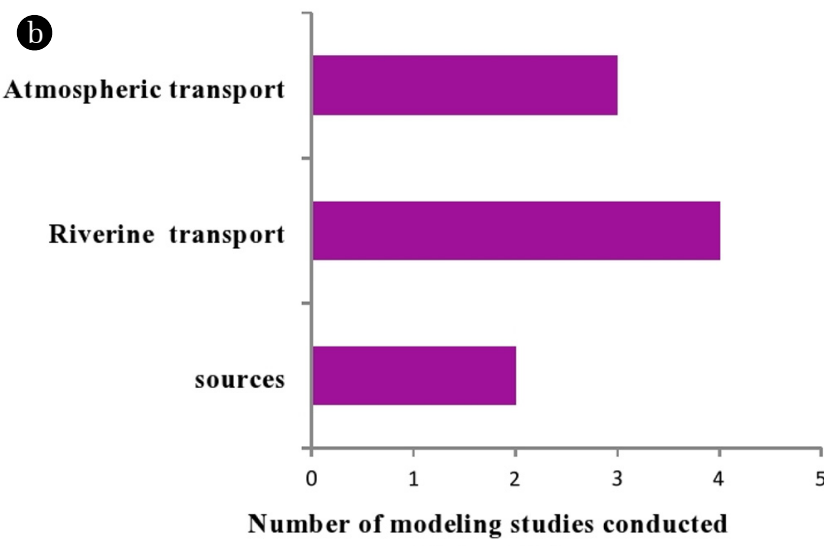

(2013 - 2020)

Fig. 4. (a) Number of studies conducted to assess the distribution and transport of plastics in the oceans (b) Number of modeling studies conducted across the world to assess the transport of plastic debris in marine environment from 2013-2020.

Island, India [57]. A study was performed to examine the distribution of microplastics in the coral islands of Maldives. The microplastic concentration was noted to be high in the seafloor sediments. Sediment samples were collected from 22 sampling sites across the reef, reef flat, and beach environments and were analyzed. The microplastic particles present in the beach, reef flat, and sediment samples were estimated to be $241.8 \pm 15.37$, $333.0 \pm 31.20$, and $249.8 \pm 23.23$, respectively [46]. The plastic debris entering the marine environment is entangled by the corals. Subsequently, microorganisms colonize the entangled plastic waste and transmit diseases to the corals [58].

\subsection{Fate and Bioavailability of Microplastics in the Marine Environment}

According to 24 expeditions (2007-2013), it has been estimated that about 270,000 tons of plastics could be floating in oceans across all five subtropical gyres, coastal Australia, Bay of Bengal, and the Mediterranean Sea [59]. Plastics are easily vulnerable to varying degrees of weathering. The degradation of plastics in the environment depends on both intrinsic (polymer type, density, size, and additive chemicals) and extrinsic (environmental) factors 


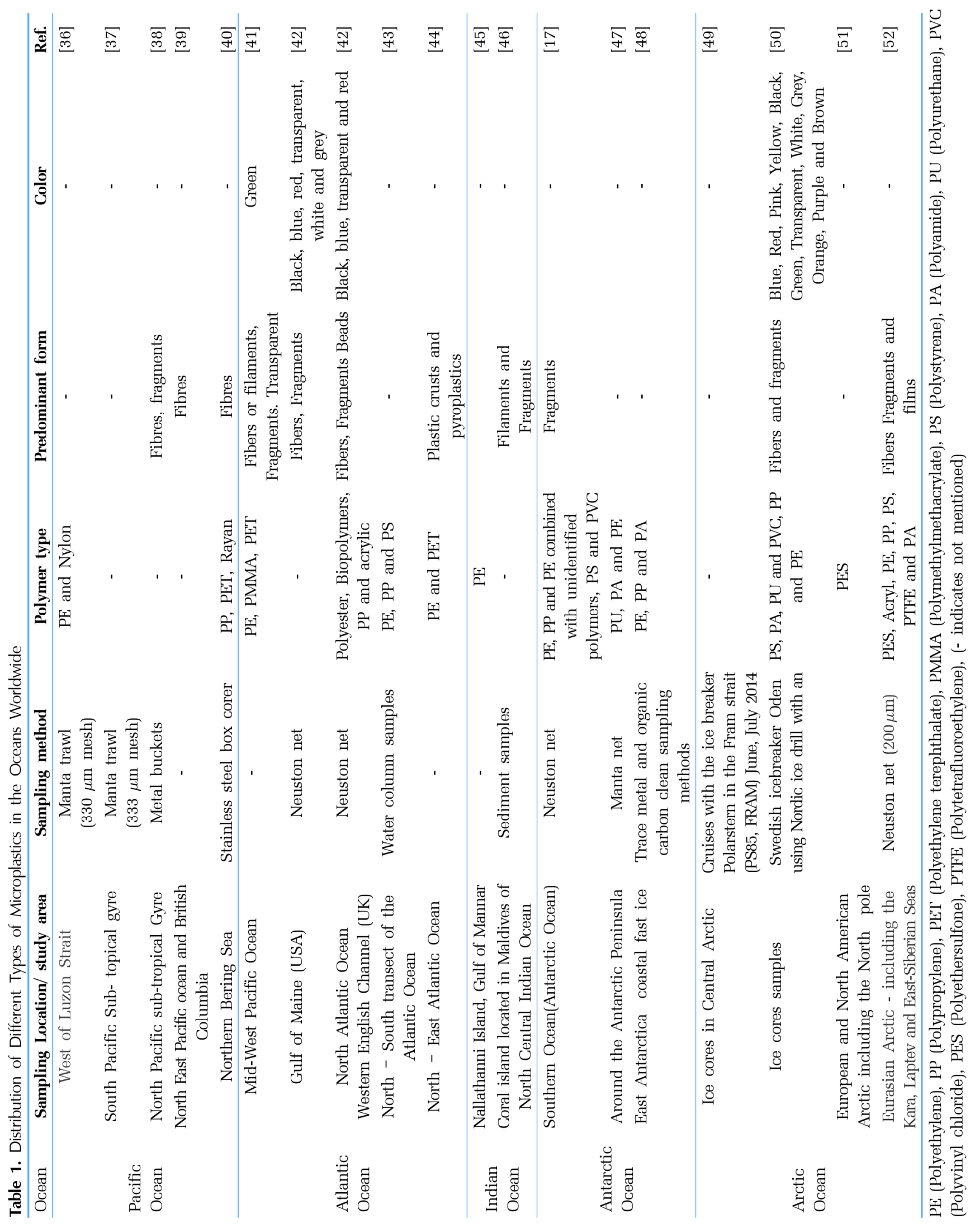


(wind, waves, and UV radiation) [60]. However, most polymer types are degraded slowly by a combination of environmental factors. Among the different factors, UV radiation plays a significant role [60]. When exposed to sunlight, chemical oxidation of the polymer takes place [61]. On exposure to UV radiation for 2 months, PET and wool fibers exhibit significant changes in surface morphology, with reduced surface charges and increased fragmentation to fibers of smaller length [60]. When the plastics are present in open environments such as the water surface and on beaches, rapid photooxidation occurs; however, biofilm formation on plastic surfaces was found to reduce UV penetration by up to $90 \%$ [62]. Microplastics are not always present on the sea surface, and these particles eventually move down to the sea floor [63, 64]. However, the relationship between the abundance of microplastics and sediment grain size has not been clearly established [65]. The microplastic deposition in sediments is mainly influenced by biologically-driven or physicochemical transport mechanisms [25]. It has been noted that aggregate formation with organic matter might play a prominent role in the transport of microplastics [66]. Furthermore, marine snows are rich in organic matter formed into aggregates $(>200$ $\mu \mathrm{m})$ [67]. In addition, the aggregates formed by marine snow are made up of fecal pellets, larvacean houses, phytoplankton, microbes, particulate organic matter, and inorganics. Aggregate formation by these organics and inorganics is governed by shear forces and Brownian movements [68]. According to Stokes's law, marine snows have higher settling rates than their individual organic and inorganic components [69]. Furthermore, due to this effect, the mass flux of organic materials from the surface waters to the deeper oceans is achieved [68], acting as a main component of the biological carbon pump [70].

The laboratory scale study by [63] revealed that when polyethylene (PE) and polyamide fragments are incorporated into snow, their bioavailability to mussels increases considerably (0-340 particles/individual for free microplastics and up to $1.6 \times 10^{5}$ particles /individual when incorporated into snows).

The tiny plastic particles that find their way to the oceans and become airborne by wind action can be carried over long distances [71]. Microplastics are resistant to environmental radiation pathways. In addition, owing to the slow degradation process, they remain in the environment for a long time [72]. Degradation is achieved by physical, chemical, and biological processes, and the rate varies with polymer type, shape, density, weathering, $\mathrm{pH}$, age, temperature, irradiation, and location in the ocean's water column [73]. The physical process of microplastic exposure to frictional forces reduces the particle size, thereby increasing the surface area to volume ratio. However, the aging of the plastic material is determined by chemical processes [72, 74]. Furthermore, the combined effect of UV radiation and chemical oxidation enhances the rate of degradation of the microplastics [72]. The chemical composition of the polymer also determines the degradation process [72].

\subsection{Distribution of Plastic Additives in the Marine Environment}

Additives such as plasticizers, flame retardants, heat stabilizers, antioxidants, UV absorbers, foaming agents, initiators, lubricants, antistatic agents, curing agents, colorants, fillers and reinforce- ments, solvents, and optical brighteners are used in the manufacture of plastics [75, 76]. The harmful chemicals added to the plastics are leached out to the environment [77] and are transported to water bodies such as rivers [78], estuaries [79, 80], and marine environments along with the disposed plastics by different means, namely industrial and municipal wastewater, atmospheric deposition, runoff, and river transport resulting from sewage sludge application in agriculture [81]. In these environments, the larger plastic items are broken down into smaller ones due to wave action and sunlight [82]. The additives present on the surfaces of the microplastics are absorbed by the marine organisms [83, 82]. Phthalate esters are considered to be endocrine-disrupting substances [84]. Di-isobutyl phthalate (DiBP) and di-n-butyl phthalate (DnBP) are the main phthalates released from PE bags, whereas dimethyl phthalate (DMP) and diethyl phthalate (DEP) are the important polyaryl ether sulfones (PAEs) released from PVC cables [85]. However, the highest level of di(2-ethylhexyl) phthalate (DEHP) was observed in the plastic accumulation zones of Northwest Pacific marginal seas, including the East China Sea [86]. High levels of DnBP and DEHP were detected in the Gulf of Mexico and North Atlantic Ocean [87] and Eastern Mediterranean Sea and Red Sea [88]. Significant concentrations (1.4 $4.9 \mu \mathrm{g} / \mathrm{g}$ ) of polycyclic aromatic hydrocarbons (PAHs), phthalates, and organotins were detected in the surface sediment samples $(0-10 \mathrm{~cm})$ collected from the North Atlantic Spanish coast, whereas polychlorinated biphenyls(PCBs) were observed in eight of the study areas at a concentration of 2.9-37 ng/g [89] during 2007. The organo tin concentration was found to be $7.7-489 \mathrm{ng} / \mathrm{g}$. Moreover, a significant correlation was found between PAH concentration and sediment particle size [89]. Inorganic plastic additives such as titanium dioxide nanoparticles, barium, sulfur, and zinc and organic plastic additives such as DEHP, DnBP, DEP, di-isobutyl phthalate (DIBP), DMP, benzaldehyde, and 2,4-di-tert-butylphenol were detected in two sediment samples collected from Norderney, a North Sea island [90]. Lubecki and Kowalewska, [77] found the occurrence of plastic derived-contaminants, namely DEHP and bisphenol A in the sediment samples collected from the human-impacted coastal zone of the Southern Baltic Sea. Thirteen PAEs with concentrations ranging from 8.13 to $11,975.6 \mu \mathrm{g} / \mathrm{kg}$ dry weight were noted in the sediment samples of the Laizhou Bay [91]. The total concentration of different phthalates such as DMP, DEP, BzBP, and DEHP estimated in the Marseille Bay during 2014 was found to be 130-1,330 ng/L (average 522 $\mathrm{ng} / \mathrm{L}$ [92]. However, the highest concentration of DEHP was observed in the bottom column of water in the accumulation zone of plastic debris in the East China Sea and Korean South Sea [86]. Furthermore, the concentration of phthalates in the seawater samples collected from Seamount in the Tropical Western Pacific Ocean was in the range of 12.13-60.69 ng/L (average $20.86 \mathrm{ng} / \mathrm{L}$ ). The phthalates detected in high concentrations, namely DnBP, DEHP, and DiBP, originated from mesoplastic leaching and atmospheric deposition [93]. While the lower molecular weight phthalate esters such as dimethyl-, diethyl-, dipropyl-, dibutyl-, diisobutyl, and butyl benzyl phthalate showed acute and chronic toxicity toward microorganisms, algae, and invertebrates, the higher molecular weight phthalate esters were not acutely or chronically toxic to the organisms [94].

The subsurface neustonic tow samples collected from Faafu 
Atoll, the Republic of Maldives, harbored different phthalate esters such as DEP, BzBP, and DEHP. Their concentrations ranged from 22 to $313 \mathrm{ng} / \mathrm{g}$, which was correlated with high microplastic contamination [95].

\section{Microplastics as Vectors for Contaminants}

The properties of microplastics in the environment keep changing due to aging processes by oxidation, UV radiation, and thermal radiation [96]. The characteristic rough surface and increased surface area achieved by aging enhance the sorption of the pollutants [97]. Liu et al. [98] reported that virgin Polyethylene microplastics (PEMPs) are not effective in transporting the trace metals ${ }^{109} \mathrm{Cd}$,

${ }^{134} \mathrm{Cs}$, and ${ }^{65} \mathrm{Zn}$. In marine environments, the plastic debris such as microplastics can carry chemical compounds (molecular weight $<1,000$ ) [83] even in extreme polar environments [99]. Laboratory studies with simulated seawater and field studies were conducted to investigate the sorption behavior of microplastics for different pollutants. Carpenter et al. [100] stated that the contaminants present in the surrounding seawater were adsorbed by polystyrene spherules collected from the Niantic Bay (North Eastern Long Island Sound, USA). Besides, the PP pellets obtained from Japanese coasts contained PCBs (4-117 ng/g) [101]. The samples gathered from Portuguese beaches during 2008 and 2009 had PE and PP adsorbed with persistent organic pollutants (POPs) (0.2-392 ng/g), PAHs (0.02 -15.56 ng.g), and dichloro diphenyl trichloro ethane (DDT) (0.16$4.05 \mathrm{ng} / \mathrm{g}$ ). Pyrene, phenanthrene, chrysene, and fluoranthene were the PAHs detected in high concentrations. In addition, the PCB congeners 18, 31, 138, and 187 were detected. The concentration of the examined pollutants was found to be high in the aged pellets [102]. In another study, the aged and black plastic pellets collected from Portuguese coastlines possessed persistent bioaccumulative and toxic chemicals (PBTC), namely PAHs (53-4,488 ng/g), PCBs (2-233 ng/g), and DDT (0.42-41 ng/g) [103]. Furthermore, microplastics can carry pesticides in the marine environment. A laboratory scale study conducted to examine the adsorption of pesticides, namely Imidacloprid, Buprofezin, and Difenoconazole, on PE revealed that more adsorption was achieved at high $\mathrm{pH}$ and low salinity [104]. The adsorption capacity of the tested pesticides on PEMPs was in the order of Difenoconazole > Buprofezin > Imidacloprid, and the adsorption process was controlled by intermolecular Van der Waals forces and the microporous filling mechanism [104].

Brennecke et al. [105] investigated the adsorption of two heavy metals, namely copper $(\mathrm{Cu})$ and Zinc $(\mathrm{Zn})$, leached from an antifouling paint to virgin PS beads and aged PVC fragments in the seawater. The released heavy metals were adsorbed by both microplastic types. However, the adsorption on PVC was higher than that on PS owing to the high surface area and polarity of PVC [105]. The sorption of heavy metals increased in the order of $\mathrm{PA}<\mathrm{PE}<$ PVC $<$ PS, irrespective of the particle size.

\subsection{Sorption of PCBs on Microplastics}

A strong relationship was noted between the sorption coefficients of the microplastics and the hydrophobicity of the sorbents [106].
The plastic samples collected from the open ocean and from remote and urban beaches harbored PCBs (derived from legacy pollution), alkyl phenols, and bisphenol at concentrations of 1-10,000 ng/g [107]. The air and water samples obtained from the equatorial Indian Ocean onboard during 2011 contained dissolved PCBs and hexachlorobenzene (HCB) (1.4-14 pg/L and 0.94-13 pg/L, respectively). The main source was found to be continental flow [108]. Zhan et al. [109] employed the batch oscillation equilibrium technique to examine the sorption of PCBs in simulated seawater. The equilibrium sorption time was found to be about $8 \mathrm{~h}$, and there was an increase in sorption capacity with decreasing particle size.

\subsection{Marine Biota and Microplastics}

The microorganisms such as Bacillus cereus [110], Pseudomonas sp. [103, 111], Micrococcus sp., and Corynebacterium sp. [112, 113] are capable of degrading plastics. The biodegradation of plastics in turn depends on environmental factors and complete or partial mineralization is achieved, resulting in the formation of various compounds, salts, minerals, and biomass [114, 115]. When the marine microalga Dunaniella salina was exposed to PE for 6 days, the growth and photosynthetic activity was enhanced. However, no impact on cell morphology (size and granularity) was observed. This effect might be due to the presence of additives such as endocrine disruptors, phthalates, and stabilizers in trace amounts in the microplastics. Their leaching might have promoted the growth and photosynthetic activity of $D$. salina [116]. The toxicity of microplastics depends on their particle size [117]. Extremely small-sized particles (nanoplastics) have severe effects on microalgae [116]. The toxicity of microplastics on microalgal species is mainly due to physical damage [118]. Song et al. [119] observed that Phaeodactylum tricornatum MASCC-0025 was inhibited on exposure to different plastic types such as polypropylene (PP), $\mathrm{PE}, \mathrm{PET}$, and polyvinyl chloride (PVC), whereas Chlorella sp. L.38 remained unaffected due to its adaptive capacity. However, exposure to micro polystyrene had no effect on the growth, morphology, or fluorescence of the free algal cells of Chaetoceros neogracile [120].

D. tertiolecta was not affected when exposed to $40 \mathrm{~nm}$ anionic carboxylated polystyrene (PS-COOH), which formed microscale aggregates (Z-average $1 \mu \mathrm{m}$ ) of up to $50 \mu \mathrm{g} / \mathrm{mol}$. However, 50 $\mathrm{nm}$ cationic amino-modified polystyrene $\left(\mathrm{PS}-\mathrm{NH}_{2}\right)$ formed nanoscale aggregates (Z-average $<200 \mathrm{~nm}$ ) and inhibited their growth [6]. In general, the adsorption capacity was enhanced significantly by the biofouling properties of the microplastics [121]. Furthermore, biofilm formation was achieved by altering the physical and chemical surface properties of the PE microplastics, which in turn changed their adsorptive capacities [122]. Recently it was established that the essential dietary components of the microalgal species, such as lipid composition is altered by microplastics [123, 124].

\subsection{Transfer of Microplastics in the Food Chain}

The microplastics present in the sea enter the food chain. The interaction of microplastics with more than 690 species present in the marine environment was studied $[125,126]$. The high surface 
Table 2. Additive Effect of Microplastics with Other Pollutants on Marine Organisms

\begin{tabular}{|c|c|c|c|c|c|}
\hline Test organism & $\begin{array}{l}\text { Concentration of } \\
\text { microplastic }\end{array}$ & Toxic compound & $\begin{array}{l}\text { Exposure } \\
\text { time }\end{array}$ & Effect & Ref. \\
\hline $\begin{array}{l}\text { Common goby } \\
\text { Pomatoschistus microps } \\
\text { (Teleostei, Gobiidae) }\end{array}$ & $100 \mu \mathrm{g} / \mathrm{L}$ & Pyrene $200 \mu \mathrm{g} / \mathrm{L}$ & $60 \mathrm{~h}$ & $\begin{array}{l}\text { 100\% mortality, Significant decrease in } \\
\text { acetylcholinesterase (AChE) activity }\end{array}$ & [147] \\
\hline $\begin{array}{l}\text { Rainbow trout } \\
\text { (Oncorhnchus mykiss) }\end{array}$ & - & $\begin{array}{l}\text { MPs coated with } \\
\qquad \mathrm{B}[\mathrm{a}] \mathrm{P}\left(\mathrm{C}^{+}\right)\end{array}$ & - & DNA damage & [148] \\
\hline $\begin{array}{l}\text { Zebra fish } \\
\text { (Danio rerio) }\end{array}$ & PS Nanoplastics (50 nm) & $\begin{array}{l}\text { 17 } \alpha \text {-ethynylestradio } \\
\quad \mathrm{l}(\mathrm{EE} 2) 2 \mu \mathrm{g} / \mathrm{L}\end{array}$ & & $\begin{array}{c}\text { Oxidative damage and body length } \\
\text { reduction }\end{array}$ & [149] \\
\hline $\begin{array}{l}\text { Seabass } \\
\text { (Dicentrarchus labrax) }\end{array}$ & $\begin{array}{c}\text { Fluorescent and red } \\
\text { polymer MP } \\
(1-5 \mu \mathrm{m} \text { diameter }) 0.26 \mathrm{mg} / \mathrm{L}\end{array}$ & Mercury $0.016 \mathrm{mg} / \mathrm{L}$ & - & $\begin{array}{c}\text { Lethargic and erratic swimming } \\
\text { behaviour }\end{array}$ & [150] \\
\hline $\begin{array}{l}\text { Water flea } \\
\text { (Daphnia magna) }\end{array}$ & $\begin{array}{l}\text { Nano sized polystyrene } \\
(100 \mathrm{~nm})\end{array}$ & $\begin{array}{l}\text { Polychlorinated } \\
\text { Biphenyls (PCBs) }\end{array}$ & $48 \mathrm{~h}$ & $\begin{array}{l}\text { Excessive amounts of nano-sized PS } \\
\text { enhanced the lethality of } D \text {. magna }\end{array}$ & [151] \\
\hline
\end{tabular}

area to volume ratio of the microplastic particles and their non-polar surface enables the sorption of chemicals. The complex mixture of contaminants thus formed is made available to the marine organisms [127]. It is evident from laboratory and field studies that microplastics are ingested by fish and other aquatic organisms [71]. The studies conducted to assess the risk of microplastic pollution on different marine organisms are compared in Table S1. Likewise, limited studies have been conducted to investigate the additive effect of microplastics with other pollutants on the marine organisms (Table 2). Majority of the studies were conducted under laboratory conditions. Hence, further opportunities are to be explored to do more research at field condition.

\subsection{Interaction of Microplastics with Microalgae}

Microalgal species play a significant role in maintaining the marine ecosystem balance. These species are affected by microplastic pollution, leading to profound impacts on aquatic food webs. Microplastics affect population regulation mechanisms by reducing the availability or absorption of nutrients orby reducing the population of predator species. The properties of microplastics exert a great influence on the microalgae, with smaller particle size and positive surface charge being associated with a higher toxicity [138]. Certain microalgal species can excrete exopolysaccharides that enable the aggregation of microplastics to form hetero-aggregates, which facilitates the vertical transport and deposition of the microplastics [139]. Limited studies have been conducted to investigate the toxic effect of microplastic pollution on microalgal species [138]. In Chaetoceros neogracile, the cellular metabolic activity and lipid content were found to decrease on exposure to PS- $\mathrm{NH}_{2}$. The microalgal oil bodies serve as an energy source and modulate their energy metabolism for the acclimatization of the cells to conditions of stress [140]. The toxic effect of microplastics was found to be exacerbated when combined with pharmaceuticals [141]. $\mathrm{PE}$, at a concentration of up to $25 \mathrm{mg} / \mathrm{L}$, exhibited no inhibitory effect on the microalgal species Isochrysis galbana [142]. In addition, the inhibitory effect of chlorpyriphos on on the algal species was reduced by PEMPs owing to its adsorption on the surface of the microplastics [142]. With increasing concentrations of poly- acrylonitrile and $\mathrm{Cu}^{2+}$, there was a significant reduction in chlorophyll a and b in Chlorella pyrenoidosa. However, the carotenoid content was increased with increasing pollutant concentration. The oxygen evolving complexes were damaged by $\mathrm{Cu}^{2+}$ pollutants [143]. Furthermore, the surface binding properties of the microplastics are affected by algal species. The experiment conducted by [144] examined the interaction between the ice alga Fragillariopsis cylindrus and microplastic beads with sea ice. In the presence of sea ice with microplastic beads, there was a significant reduction in the number of algal cells; however, with increasing salinity, the number of beads was considerably reduced. When the salinity of the ice was increased, the abundance of the beads was augmented.

\subsection{Interaction of Algae with Plastic Additives}

A laboratory-scale study was conducted to examine the inhibitory effect of DEPand DnBP on algal species, namely Chaetoceros muelleri, Cylindrotheca closterium, and Dunaliella salina. After $96 \mathrm{~h}$ of exposure, the tested green algal species, except $C$. Closterium, were found to be sensitive to phthalic acid ester [145]. DnBP, at concentrations $>10^{-5} \mathrm{M}$, inhibited the growth and photosynthesis of $C$. emersonii strain 211/8h and Selenastrum capricornatum CCAP strain 278/4 [145]. Furthermore, the damage caused to cell membrane, chloroplasts, and protein rings by DnBP (2-20 mg/L) was higher for $S$. obliquus than for $C$. vulgaris.

The distribution of eight individual phthalate esters (i.e., dimethyl, diethyl, di-iso-butyl, di-n-butyl, butylbenzyl, di(2-ethylhexyl), di-n-octyl, di-n-nonyl, and five commercial isomeric mixtures (i.e., di-iso-hexyl (C6), di-iso-heptyl (C7), di-iso-octyl (C8), di-iso-nonyl (C9), and di-iso-decyl (C10)) in a marine food web was investigated by [146].

\subsection{Effect of Microplastics on Corals}

The major source of microplastic pollution in the marine environment is the land. Owing to microplastic pollution, the coastal ecosystems containing coral reefs are endangered. Initially, the microplastic occurrence in the scleractinin corals was reported in the Great Barrier Reef of Australia [152]. The microplastics are devoured 
by the corals by ingestion, retention of plastic fragments, and digestion [153]. The laboratory-based study revealed that the corals exposed to microplastics consumed approximately $50 \mu \mathrm{g} / \mathrm{cm}^{2} / \mathrm{h}$ [55]. The retention of plastic fragments in the mesenterial tissue of the corals lowers their feeding capacity and compromises the energy resources [55]. Furthermore, the biofilms associated with plastic fragments promote the transmission of pathogens, which exerts a severe impact on the corals [154].

\subsection{Phthalates in Marine Organisms}

In recent years, much attention has been paid to the occurrence of microplastics and their potential impact on marine organisms. The presence of plastic additives in the marine environment and in the organisms inhabiting such niches indicates plastic exposure in the region [155]. The occurrence of plastic additives in marine organisms belonging to different species with different feeding habits has been explored. Marine organisms accidentally ingest the microplastics during filtration or preying [156, 157]. In addition, the marine organisms ingest microplastics by misunderstanding them as prey [158]. The presence of plastic particles in more than 100 marine species, including zooplanktons, marine birds, and reptiles, has been documented [159].

\section{Constraints in Quantifying the Microplastic Content in the Marine Environment}

Microplastic particles in the marine environment have not been adequately estimated, and their amount in the global ocean environment has been poorly studied [160]. In general, surveying and monitoring is done in the shoreline as part of cleanup activities or other community events. However, the obtained information does not depict the actual scenario. In addition, sampling from the oceans is an expensive and arduous task. The sampling is usually not replicated due to practical difficulties and the associated costs. Mostly, surface sampling is done using trawls, which provides the quantity of floating objects only. However, the ocean is vast and complex, with the changing circulation pattern leading to heterogeneity. Besides, for statistical analysis, the data required is high, which can be satisfied only by large sample sizes [160].

In general, long-term monitoring of microplastics in the marine environment is time consuming and expensive. For monitoring microplastic abundance in the oceans, different approaches are followed throughout the world, but it is unclear whether they are properly standardized [29]. Furthermore, our current knowledge on microplastic distribution in the oceans is insufficient to estimate the total plastic load. Until now, a standard method is not available to study the abundance and distribution of microplastics and their effects on the marine organisms. Hence, it is difficult to make comparisons between different areas of study [161]. What's more, the available data on the quantities and characteristics of buoyant ocean plastics are obtained from samples collected using small sea surface trawls, which were originally developed to collect neustonic plankton [162]. Owing to the small aperture (0.5-1mm width, 0.15-1mm depth) and limited surface area covered, the rarer and larger plastic debris, including bottles and buoys, are either excluded or under estimated [163]. Hence, it is hard to quantify the microplastic distribution with the available data [160].

\section{Application of Models to Assess the Source, Quantity and Risk of Plastic Debris Transported to Marine Environments: the Current Status}

\subsection{Sources and Transport}

Models are used to study the major drivers at a global scale, and these can be potentially scaled down to consider local processes [164]. From Table 3, it is known that modeling studies can help to investigate the quantity of microplastics from land to sea and to assess the important sources of microplastics. But the input data used for modeling studies are based on assumptions with the literature support. In the case of riverine transport of microplastics, the settling velocity of the particle and the density of fluid are the important parameters. The density of water varies with temperature and salinity. The salinity of the sea varies due to rain and freshwater sources. Therefore, monitoring is difficult due to large temporal and spatial variations in the amount of plastic debris and its fate in the marine environment. The number of modeling studies conducted across the world to explain the transport of microplastics to the marine environment is illustrated in Fig. 4(b).

Siegfried et al [27] applied a model to estimate the microplastic flux from land to sea in European rivers. The model was applied for river basins draining into the North Sea, Baltic Sea, and Black Sea and for the European river basins draining into the Atlantic Ocean to calculate the microplastic fluxes for the year 2000 and to predict the scenario for the year 2050. The model utilized was inspired by a global model for nutrients, namely, the Global NEWS (Nutrient Export from Watersheds) model [173, 174]. The approach was to derive the river export of microplastics from point sources as a function of human activities on land and river retention. Two existing scenarios from the Millennium Ecosystem Assessment, namely the Global Orchestration (GO) and the Adaptive Mosaic (AM), were used for this study. The output from this modeling study indicated that there is a great variation in microplastic loads among the rivers owing to the differences in socioeconomic and technological characterizations. Furthermore, the study revealed that the Mediterranean Sea received the highest microplastic load, wherein tire and road wear particles constituted the major sources of microplastics. In addition, it was projected that the export of microplastics to the Mediterranean Sea is likely to increase in the future.

Recently, a modeling study conducted based on the concept of mismanaged plastic wastes are substantially greater than field measurement in which Human Development Index(HDI) was used as the main predictor. By this study it is known that the global plastic outflows from 1,518 main rivers were in the range of 57,000265,000 MT/year in 2018. In addition, with increased plastic production and human development global riverine plastic outflow is projected to peak in 2028 in a modeled trajectory of 2010-2015 [168]. 
Table 4. Modeling Studies Conducted to Assess the Risk of Microplastics on Marine Organisms

\begin{tabular}{lcc}
\hline Organisms & Model /tool used & Outcome \\
\hline $\begin{array}{l}\text { Mussels } \\
\text { (Mytilus galloprovincialis) }\end{array}$ & $\begin{array}{c}\text { Generic DEB Accumulation } \\
\text { Model }\end{array}$ & $\begin{array}{c}\text { Accumulation of microplastics depends on concentration, } \\
\text { temperature and chlrophyll a of surrounding }\end{array}$ \\
\cline { 2 - 3 } & Linear Regression Model & $\begin{array}{c}\text { Retention of smaller particles, Faster elimination of larger particles } \\
\text { [186] }\end{array}$ \\
\hline $\begin{array}{l}\text { Sea bass } \\
\text { (Dicentrarchus labrax) }\end{array}$ & R- software & Additive effect of pyrene and PE and PS was higher \\
\hline
\end{tabular}

PE- Polyethylene, PS - Polystyrene, PCBs-polychlorinated Biphenyls, BFRs - Brominated Flame Retardants

The model developed by [169], used correlation between the observed microplastic concentrations in rivers and basin characteristics namely urban area ratio and population density.

The modeling study performed by [175] estimated the past, present, and future concentrations based on the global plastic production data. The past and future concentrations of the microplastics were computed using the 1950-2016 (historical annual plastic production) and 2017-2100 (global growth in plastic production) figures. The assumptions made for this study were (1) of the total plastic production, $1.75-4.62 \%$ becomes marine litter $\left(f_{\mathrm{ML}}\right)$ [9] (2) about $90 \%$ of the marine litter that enters the sea ends up on the seabed $\left(f_{\text {seabed }}=94 \%\right)$, whereas $5 \%$ is washed ashore $\left(f_{\text {ashore }}\right.$ $=5 \%$ ) and the remaining becomes free-floating microplastics [176]. In the above mentioned study, assuming minimal input of plastics into the marine environment and maximal weight loss, the total global mass of floating microplastics in 2010 was estimated to be $4.9 \times 10^{5}$ tons. However, it is predicted that by 2100 , the mass of floating microplastics will reach $2.5 \times 10^{7}-1.3 \times 10^{8}$ tons (best-case and worst-case scenarios, respectively). To predict the pelagic microplastic content in the Pacific Ocean, numerical modeling was done. The study revealed that the abundance distribution (52\% of the global total) of microplastics was found in the region described as the Great Pacific Garbage Patch $[177,178]$ and in the East Asian Seas [179].

To study the distribution of microplastics in the marine environment, numerical modeling approach has been used to refine the simulations [160]. The fluxes between the coast and the ocean, movement between coast and ocean accumulation, and fluxes between the oceans (surface, water column, or floor) and the biota were considered as the important parameters. In general, numerical modeling has been used to hind cast the source of microplastics in the ocean [180]. Recently, an unmanned aerial vehicle combined with an image processing method based on deep learning was employed to examine the microplastic pollution in the marine environment [181].

An Eulerian approach was employed to study the accumulation of seven plastic types within the five garbage patches in the global oceans. The results of the simulations revealed that the vertical movement of the plastic particles occurs throughout the water column as well as on the seafloor. However, the outcome of the model was that negatively buoyant plastics tend to accumulate within the deepest regions of the seafloor, loosely following the bathymetry. Furthermore, the neutrally buoyant plastics lead to the potentially ubiquitous presence of microplastics and nanoplastics [182]. There was a huge disparity between the measured and modeling results, which could be attributed to the large uncertainty in the microplastic values assigned to the world's countries or regions [183]. However, the conceptual model developed to simulate the effect of plastics on the bioaccumulation of POPs [184]. Model analysis showed that PS will have a decreasing effect on bioaccumulation, governed by dilution. Furthermore, PS that have low affinity for POPs have a marginal decreasing effect on bioaccumulation governed by dilution. However, for stronger sorbents (PE), the dilution, carrier, and cleaning mechanisms are more substantial [184].

\subsection{Risk to Marine Organisms}

Very few modeling studies were conducted to assess the risk of microplastics on the marine organisms. The comparison of modeling studies conducted to investigate the accumulation of microplastics in different marine organisms is presented in Table 4.

The size, shape, concentration and duration of exposure are the important factors to determine the risk of microplastic pollution on marine organisms [188]. The data available to conduct modeling studies are scanty. Further, specific models to assess the risk of microplastic pollution on marine organisms are not available. The studies conducted so far were conducted with Genereic DEB accumulation model [185], linear regression model [186], R-Software [26] and regression model [187]. Further, it is impossible to predict the risks of ingesting microplastics by marine organisms due to lack of measured data to validate the models.

\section{Conclusions and Future Perspectives}

In this review, studies conducted on the distribution of microplastics in the five oceans, namely the Pacific, Atlantic, Indian, Antarctic, and Arctic oceans, and the coral islands were reviewed. Based on the examined literature, it could be concluded that only few studies $(<5)$ have been conducted to quantify the microplastics in the five oceans. In general, samples were collected from surface and subsurface regions. Fibers, fragments, and beads were the major forms of microplastic samples collected. The important types of plastics examined were PE, PP, and beads. However, the forms and types of microplastics were not uniform. Furthermore, different sampling methods were followed by researchers, and the mesh size was also not uniform. The output might vary depending on the sampling method, location of sampling, mesh size used, extraction methods, and the season. The coral islands were given 
the least importance. Besides, few studies were conducted to demonstrate the presence of plastic additives in the marine environment. Based on the results, it is very difficult to determine the source of the additives. Even though the interaction of microplastics and plastic additives with marine algal species was reviewed, most studies were conducted in the laboratory with spiking. Algae, the primary producers in the marine ecosystem, were not given adequate importance. In addition, few modeling approaches were used to assess the microplastic pollution and the associated risks. Future research is required to bridge the above mentioned research gaps. The following aspects warrant immediate research attention: (1) standard sampling and extraction methods for different conditions (2) distribution of microplastics in the coral islands and the effects on the corals (3) correlation of microplastic pollution with marine algal species (4) development of most suitable models considering all the factors (5) fragmentation rate and sinking rate of plastic debris during transport is to be studied. Specific models should be developed to assess the import of plastics from different sources, including land and atmosphere, the pathway of transport (water, air), and the risks associated with plastic pollution. Besides, future research should focus on modeling, which is likely to provide useful insights into the accumulation of plastics in the marine environment. Such studies are likely to reveal the most economical ways of managing the plastic waste and maintaining a healthy ecosystem.

\section{Author Contributions}

A.M.S (Assistant Professor (Sr. Gr.)) conceived the idea and wrote the manuscript. B.M. (Assistant Professor) and G.D. (Assistant Professor) provided technical support in the area of risk assessment and modeling respectively.

\section{References}

1. Geyer R, Jambeck JR, Law KL. Production, use, and fate of all plastics ever made. Sci. Adv. 2017;3(7):e1700782.

2. Plastic Europe. An analysis of European plastics production, demand and waste data [Internet]. Plastics - the Facts; 2020 [cited 8 December 2020]. Available from: https://www.plasticseurope.org/application/files/8016/1125/2189/AF_Plastics_ the_facts-WEB-2020-ING_FINAL.pdf.

3. World Economic Forum. The New Plastics Economy Rethinking the future of plastics [Internet]. Annual Report; 2016 [cited 4 December 2020]. Available from: http://www3.weforum.org/ docs/WEF_The_New_Plastics_Economy.pdf.

4. Galloway TS. Micro- and nano-plastics and human health, Marine Anthropogenic Litter. Springer, Chem; 2015. p. 343-366.

5. Gallagher A, Rees A, Rowe R, Stevens J, Wright P. Microplastics in the Solent estuarine complex, UK: an initial assessment. Mar. Pollut. Bull. 2016;102:243e249-243e249.

6. Lambert S, Wagner M. Characterization of nanoplastics during the degradation of polystyrene. Chemosphere 2016;145:265-268.

7. Hartmann NB, Hubber T, Thompson RC, et al. Are we speaking the same language? Recommendations for a definition and cate- gorization framework for plastic debris. Environ. Sci. Technol. 2019;53:1039-1047

8. Besseling M, Hopmans EC, Sinninghe DJS, Villanueva L. Benthic archaea as potential sources of tetraether membrane lipids in sediments across an oxygen minimum zone. Biogeosciences 2018;15(13):4047-4064.

9. Jambeck JR, Geyer, Wilcox C, et al. Plastic waste inputs from land into the ocean. Science 2015;347(6223):768-771.

10. Lebreton L, van der Zwet J, Damsteeg JW, et al. River plastic emissions to the world's oceans. Nat. Commun. 2017;8:15611.

11. Anderson JC, Park BJ, Palace VP. Microplastics in aquatic environments: Implications for Canadian ecosystem. Environ. Pollut. 2016;218:260-280.

12. Liu K, Wang X, Song Z, Wei N, Li D. Terrestrial plants as a potential temporary sink of atmospheric microplastics during transport. Sci. Total Environ. 2020;742:140523.

13. Evangeliou N, Grythe H, Klimont Z, et al. Atmospheric transport is a major pathway of microplastics to remote regions. Nat. Commun. 2020;11:3381.

14. Schmidt C, Krauth T, Wagner S. Export of Plastic Debris by Rivers into the Sea. Environ. Sci. Technol. 2017;5(21):1224612253.

15. Kara LL. Plastics in the Marine Environment. Ann. Rev. Mar. Sci. 2017;9(1):205-229.

16. Cózar A, Marti E, Duarte CM, et al. The Arctic Ocean as a dead end for floating plastics in the North Atlantic branch of the Thermohaline Circulation. Sci. Adv.2017;3:e1600582.

17. Isobe $A$, Uchimaya-Matsumoto $K$, Uchida $K$. Tokai $T$. Microplastics in the Southern Ocean. Mar. Pollut. Bull. 2017;114(1):623-626.

18. Tekman MB, Krumpen T, Bergmann M. Marine litter on deep Arctic seafloor continues to increase and spreads to the North at the HAUSGARTEN observatory. Deep Sea Res. 2017;1120:88-99.

19. Karthik R, Robin RS, Purvaja R, et al. Microplastics along the beaches of southeast coast of India. Sci. Total Environ. 2018;645:1388-1399.

20. Maximenko N, Corradi P, Law KL, et al. Toward the Integrated Marine Debris Observing System. Front. Mar. Sci. 2019;6:447.

21. Wichmann D, Delandmeter P, van Sebille E. Influence of NearSurface Currents on the Global Dispersal of Marine Microplastic. JGR Oceans. 2019;124(8):6086-6096.

22. Wright SL, Thompson RC, Galloway TS. The physical impacts of microplastics on marine organisms: A review. Environ. Pollut. 2013;178:483-492.

23. Compa M, Alomar C, Wilcox C, et al. Risk assessment of plastic pollution on marine diversity in the Mediterranean Sea. Sci. Total Environ. 2019;678:188-196.

24. Lusher A, Tirelli V, O’Connor I, et al. Microplastics in Arctic polar waters: the first reported values of particles in surface and sub-surface samples. Sci. Rep. 2015;5:14947.

25. Avio CG, Gorbi S, Ragoli F. Plastics and microplastics in the oceans: From emerging pollutants to emerged threat. Mar. Environ. Res. 2017;128:2-11.

26. Avio CG, Gorbi S, Milan M. Pollutants bioavailability and toxicological risk from microplastics to marine mussels. Environ. Pollut. 2019;198:211-222.

27. Siegfried M, Koelmans AA, Besseling E, Kroeze C. Export of 
microplastics from land to sea. A modelling approach. Water Res. 2017;127:249-257.

28. Horton AA, Walton X, Spurgeon DJ, Lahive E, Svendsen C. Microplastics in freshwater and terrestrial environments: Evaluating the current understanding to identify the knowledge gaps and future research priorities. Sci. Total Environ. 2017;586:127-141.

29. Barnes DKA, Galgani FG, Thompson RC, Barlaz M. Accumulation and fragmentation of plastic debris in global environments. Philos Trans R Soc. Lond B Biol. Sci. 2009;364(1526):1985-1998.

30. Kumar MV, Sheela AM. Effect of plastic film mulching on the distribution of plastic residues in agricultural fields. Chemosphere 2021;273:128590.

31. Kühn S, Bravo Rebolledo EL, van Franeker JA. Deleterious Effects of Litter on Marine Life. In: Bergmann M., Gutow L, Klages M, eds. Marine Anthropogenic Litter, Springer, Cham; 2015. p. 75-116.

32. Essel R, Engel L, Carus M, Ahrens R. Sources of Microplastics Relevant to Marine Protection in Germany. Texte 2015;64:1-48

33. Mintening SM, Int-Veen I, Loder MGJ, Primpke S, Gerdts G. Identification of microplastic in effluents of waste water treatment plants using focal plane array-based micro-Fourier-transform infrared imaging. Water Res. 2017;108:365-372.

34. Wolf S, Kerpen J, Prediger J, Barkmann L, Müller L. Determination of the microplastics emission in the effluent of a municipal waste water treatment plant using Raman microspectroscopy. Water Res. X. 2019;2:100014.

35. Silambarasan P, Sheela AM. Microplastics Distribution in Freshwater Lake and Drinking Water Treatment Plant: A Case Study. Indian J. Ecol. 2020;47(4):930-933.

36. Pan Z, Liu Q, Sun Y, Sun X, Lin H. Environmental implications of microplastic pollution in the Northwestern Pacific Ocean. Mar. Pollut. Bull. 2019;146:215-224.

37. Eriksen M, Maximenko N, Thiel M, et al. Plastic pollution in the South Pacific subtropical gyre. Mar. Pollut. Bull. 2013; 68(1-2):71-76.

38. Brandon JA, Freibott A, Sala LM. Patterns of suspended and salp-ingested microplastic debris in the North Pacific investigated with epifluorescence microscopy. Limnol. Oceanogr Lett. 2020;5(1):46-53.

39. Desforges JW, Galbraith M, Dangerfield N, Ross PS. Widespread distribution of microplastics in subsurface seawater in the NE Pacific Ocean. Mar. Pollut. Bull. 2014;79(1-2):94-99.

40. Mu J, Zhang S, Qu L, et al. Microplastics abundance and characteristics in surface waters from the Northwest Pacific, the Bering Sea, and the Chukchi Sea. Mar. Pollut. Bull. 2019;143:58-65.

41. Wang S, Chen H, Zhou X, et al. Microplastic abundance, distribution and composition in the mid-west Pacific Ocean. Environ. Pollut. 2020;262:114125.

42. Lindeque PK, Cole M, Coppock R, et al. Are we underestimating microplastic abundance in the marine environment? A comparison of microplastic capture with nets of different mesh-size. Environ. Pollut. 2020;265(Part A):114721.

43. Pabortsava K, Lampitt RS. High concentrations of plastic hidden beneath the surface of the Atlantic Ocean. Nat. Commun. 2020;11:4073.

44. Ehlers S, Ellrich J. First record of 'plasticrusts' and 'pyroplastic' from the Mediterranean Sea. Mar. Pollut. Bull. 2020;151:110845. 45. Krishnakumar S, Srinivasalu S, Saravanan P, Vidyasakar A, Magesh NS. A preliminary study on coastal debris in Nallathanni Island, Gulf of Mannar Biosphere Reserve, Southeast coast of India. Mar. Pollut. Bull. 2018;131:547-551.

46. Patti TB, Fobert EK, Reeves SE, da Silva KB. Spatial distribution of microplastics around an inhabited coral island in the Maldives, Indian Ocean. Sci. Total Environ. 2020;748:141263.

47. Lacerda ALDF, Rodrigues LDS, van Sebille E, et al. Plastics in sea surface waters around the Antarctic Peninsula. Sci. Rep. 2019;9:3977.

48. Kelly A, Lannuzel D, Rodemann T, Meiners KM, Auman HJ. Microplastic contamination in east Antarctic sea ice. Mar. Pollut. Bull. 2020;154:111130.

49. Peeken I, Primpke S, Beyer B, et al. Arctic sea ice is an important temporal sink and means of transport for microplastic. Nat. Commun. 2018;9:1505.

50. Kanhai LDK, Gardfeldt K, Krumpen T, et al. Microplastics in sea ice and seawater beneath ice floes from the Arctic Ocean. Sci. Rep. 2020;10:5004.

51. Ross PS, Chastain S, Vassilenko E, et al. Pervasive distribution of polyester fibres in the Arctic Ocean is driven by Atlantic inputs. Nat. Commun. 2021;12:106.

52. Yakushev E, Gebruk A, Osadchiev A, et al. Microplastics distribution in the Eurasian Arctic is affected by Atlantic waters and Siberian Rivers. Commun. Earth Environ. 2021;2:23.

53. Birkeland CR. Introduction. In: Birkeland C.R., eds. Life and Death of Coral Reefs. New York: Chapman and Hall; 1997. p. 1-12.

54. Huang W, Chen M, Song B, et al. Microplastics in the coral reefs and their potential impacts on corals: A mini-review. Sci. Total Environ. 2021;762:143112.

55. Hall NM, Berry KLE, Rintoul L, et al. Microplastic ingestion by scleractinian corals. Mar Biol. 2015;162:725-732.

56. Ding J, Jiang F, Li J, et al. Microplastics in the coral reef systems from Xisha islands of South China Sea. Environ. Sci. Technol. 2019;53(14):8036-8046.

57. Jeyasanta KI, Patterson J, Grimsditch G, Edward JKP. Occurrence and characteristics of microplastics in the coral reef, sea grass and near shore habitats of Rameswaram Island, India. Mar. Pollut. Bull. 2020;160:111674.

58. Lamb JB, Willis BL, Fiorenza EA, et al. Plastic waste associated with disease on coral reefs. Science 2018;359(6374):460-462.

59. Eriksen M, Lebreton LCM, Carson HS, et al. Plastic Pollution in the World's Oceans: More than 5 Trillion Plastic Pieces Weighing over 250,000 Tons Afloat at Sea. PLOS ONE. 2014;9(12):e111913.

60. Sorensen L, Rogers E, Altin D, Salaberria I, Booth AM. Sorption of PAHs to microplastic and their bioavailability and toxicity to marine copepods under co-exposure conditions. Environ. Pollut. 2020;258:113844.

61. Andrady AL. Persistence of Plastic Litter in the Oceans. In: Bergmann M., Gutow L., Klages M, eds. Marine Anthropogenic Litter. Springer, Cham; 2015. p. 57-72.

62. Weinstein JE, Crocker BK, Gray AD. From macroplastic to microplastic. Degradation of high-density polyethylene, polypropylene, and polystyrene in a salt marsh habitat. Environ. 
Toxicol. Chem. 2016;35(7):1632-1640.

63. Porter AW, Wolfson SJ, Young L. Pharmaceutical transforming microbes from wastewater and natural environments can colonize microplastics. AIMS Environ. Sci. 2020;7(1):99-116.

64. Zalasiewicz J, Waters CN, Ivar do Sul JA, et al. The geological cycle of plastics and their use as a stratigraphic indicator of the Anthropocene. Anthropocene 2016;13:4-17.

65. Alomar C, Estarellas F, Deudero S. Microplastics in the Mediterranean Sea: Deposition in coastal shallow sediments, spatial variation and preferential grain size. Mar. Environ. Res. 2016;115:1-10.

66. Lisbeth VC, Michiel C, Michiel BV, Colin RJ. Microplastics are taken up by mussels (Mytilus edulis) and lugworms (Arenicola marina) living in natural habitats. Environ. Pollut. 2015;199:10-17.

67. Zhao S, Danley M, Ward JE, Li D, Mincer TJ. An approach for extraction, characterization and quantitation of microplastic in natural marine snow using Raman microscopy. Anal. Methods. 2019;9(9):1470-1478.

68. Newell CR, Pilskaln C, Robinson SMC, McDonald S. The contribution of marine snow to the particle food supply of benthic suspension feeder, Mytilus edulis. J. Exp. Mar. Biol. Ecol. 2014;321:109-124.

69. Long M, Moriceau B, Gallinari M, Lambert C, Huvet A, Raffray $\mathrm{J}$, et al. Interactions between microplastics and phytoplankton aggregates: impact on their respective fates. Mar. Chem. 2015;175:39-46.

70. Turner JT. Zooplankton fecal pellets, marine snow, phytodetritus and the ocean's biological pump. Prog. Oceanogr. 2015;130:205-248.

71. Kara GT, Kara M, Bayram A, Gunduz O. Assessment of seasonal and spatial variations of physicochemical parameters and trace elements along a heavily polluted effluent-dominated stream. Environ. Monit. Assess. 2017;189:585.

72. Klein S, Dimzon IK, Eubeler JP, Knepper TP. Analysis, Occurrence, and Degradation of Microplastics in the Aqueous Environment In: M. Wagner M, Lambert, S eds. Freshwater Microplastics. The Hand Book of Environmental Chemistry. Germany: Springer, Cham; 2018. p. 51-67.

73. Smith M, Love DC, Rochman CM, Neff RA. Microplastics in Seafood and the Implications for Human Health. Curr. Environ. Health Rpt. 2018;5:375-386.

74. Kooi M, Besseling E, Kroeze C, van Wezel AP, Koelmans AA. Modelling the fate and transport of plastic debris in fresh waters: Review and guidance. In: Wagner M, Lambert S, eds. The Handbook of Environmental Chemistry. Germany: Springer, Cham; 2017. p. 58.

75. Fishbein L. An overview of environmental and toxicological aspects of aromatic hydrocarbons II. Toluene. Sci. Total Environ. 1985;42(3):267-288.

76. Lithner D, Larsson A, Dave G. Environmental and health hazard ranking and assessment of plastic polymers based on chemical composition. Sci. Total Environ. 2011;409(18):3309-3324.

77. Lubecki L, Kowalewska G. Plastic-derived contaminants in sediments from the coastal zone of the southern Baltic Sea. Mar. Pollut. Bull. 2019;146:255-262.

78. Weizhen Z, Xiaowei Z, Peng G, et al. Distribution and risk assessment of phthalates in water and sediment of the Pearl River Delta. Environ. Sci. Pollut. Res. 2020;27:12550-12565.

79. Ramzi A, Gireeshkumar TR, Rahman HH, et al. Distribution and contamination status of phthalic acid esters in the sediments of a tropical monsoonal estuary, Cochin - India. Chemosphere 2018;210:232-238.

80. Ramzi A, Gireeshkumar TR Rahman H. Phthalic acid esters - A grave ecological hazard in Cochin estuary, India. Mar. Pollut. Bull. 2020;152:10899.

81. van den Berg P, Huerta-Lwanga T, Corradini F, Geissen V. Sewage sludge application as a vehicle for microplastics in eastern Spanish agricultural soils. Environ. Pollut. 2020;261: 114198.

82. Enfrin M, Lee J, Gibert Y, Basheer F, Kong L, Dumee LF. Release of hazardous nanoplastic contaminants due to microplasticsfragmentation under shear stress forces. J. Hazard. Mater. 2020;384:121393.

83. Teuten EL, Saquing JM, Knappe DRU, et al. Transport and release of chemicals from plastics to the environment and to wildlife. Phil. Trans. R. Soc. B. 2009;364:2027-2045.

84. Foster PMD, Mylchreest E, Gaido KW, Sar M. Effects of phthalate esters on the developing reproductive tract of male rats. APMIS. 2015;109:S272-S277.

85. Paluselli A, Fauvelle V, Galgani F, Sempere R. Phthalate Release from Plastic Fragments and Degradation in Seawater. Environ. Sci. Technol. 2019;53(1):166-175.

86. Paluselli A, Kim S. Horizontal and vertical distribution of phthalates acid ester (PAEs) in seawater and sediment of East China Sea and Korean South Sea: Traces of plastic debris. Mar. Pollut. Bull. 2020;151:110831.

87. Giam CS, Chan HS, Neff GS, Atlas EL. Phthalate ester plasticizers: A new class of marine pollutant. Science 1978;199(4327): 419-421.

88. Vered G, Kaplan A, Avisar D, Shenkar N. Using solitary ascidians to assess microplastic and phthalate plasticizers pollution among marine biota: A case study of the Eastern Mediterranean and Red Sea. Mar. Pollut. Bull. 2019;138:618-625.

89. Antizar-Ladislao B. Polycyclic aromatic hydrocarbons, polychlorinated biphenyls, phthalates and organotins in northern Atlantic Spain's coastal marine sediments. J. Environ. Monit. 2009;11:85-91.

90. Ludovic H, Dehaut A, Paul-Pont I, et al. Occurrence and effects of plastic additives on marine environments and organisms: A review. Chemosphere 2017;182:781-793.

91. Zhang, B, Gao Y, Lin C, Yang W, Liu X, Wang Y. Spatial distribution of phthalate acid esters in sediments of the Louzhou Bay and geochemical variables. Sci. Total Environ. 2020;722: 137912.

92. Palucelli A, Fauvelle V, Schmidt N, Galgani F, Net S, Sempere R. Distribution of phthalates in Marseille Bay (NW Mediterranean Sea). Sci. Total Environ. 2018;621:578-587.

93. Zhang Y, Gao T, Kang S, Silanpaa M. Importance of atmospheric transport for microplastics deposited in remote areas. Environ. Pollut. 2019;254(Part A):112953.

94. Staples CA, Peterson DR, Parkerton TF, Adams WJ. The environmental fate of phthalates esters: a literature review. Chemosphere 1997;35:667-749. 
95. Saliu F, Montano S, Leoni B, Lasagni M, Galli P. Microplastics as a threat to coral reef environments: Detection of phthalate esters in neuston and scleractinian corals from the Faafu Atoll, Maldives. Mar. Pollut. Bull. 2019;142:234-241.

96. Celina MC. Review of polymer oxidation and its relationship with materials performance and lifetime prediction. Polym. Degrad. Stab. 2013;98(12):2419-2429.

97. Liu J, Zhang T, Tian L, et al. Aging Significantly Affects Mobility and Contaminant-Mobilizing Ability of Nanoplastics in Saturated Loamy Sand. Environ. Sci. Technol. 2019;53(10): 5805-5815

98. Besson M, Jacob H, Oberhaensli F, et al. Preferential adsorption of $\mathrm{Cd}$, Cs and $\mathrm{Zn}$ onto virgin polyethylene microplastic versus sediment particles. Mar. Pollut. Bull. 2020;156:111223.

99. Caruso G. Microplastics as vectors of contaminants. Mar. Pollut. Bull. 2019;146:921-924.

100. Carpenter EJ, Anderson SJ, Harvey GR, Miklas HP, Peck BB. Polystyrene spherules in coastal waters. Science 1972;178 (4062):749-50.

101. Mato Y, Isobe T, Takada H, Kanehiro H, Ohtake C, Kaminuma T. Plastic resin pellets as a transport medium for toxic chemicals in the marine environment. Environ. Sci. Technol. 2001;35(2):318-324.

102. Frias JPGL, Sobral P, Ferreira AM. Organic pollutants in microplastics from two beaches of the Portuguese coast. Mar. Pollut. Bull. 2010;60(11):1988-1992.

103. Antunes JC, Frias JGL, Micaelo AC, Sobral P. Resin pellets from beaches of the Portuguese coast and adsorbed persistent organic pollutants. Estuar. Coast. Shelf Sci. 2013;130:62-69.

104. Li H, Wang F, Li J, Deng S, Zhang S. Adsorption of three pesticides on polyethylene microplastics in aqueous solutions: Kinetics, isotherms, thermodynamics, and molecular dynamics simulation. Chemosphere. 2021;264(Part 2):128556.

105. Brennecke D, Duarte B, Paiva F, Caçador I, Canning-Clode J. Microplastics as vector for heavy metal contamination from the marine environment. Estuar. Coast. Shelf Sci. 2016;178: 189-195.

106. Hüffer T, Hofmann T. Sorption of non-polar organic compounds by micro-sized plastic particles in aqueous solution. Environ. Pollut. 2014;214:194-201.

107. Hirrari H, Takada H, Ogata Y, et al. Organic micropollutants in marine plastics debris from the open ocean and remote and urban beaches. Mar. Pollut. Bull. 2011;62(8):1683-1692.

108. Huang Y, Li J, Xu Y, et al. Polychlorinated biphenyls (PCBs) and hexachlorobenzene (HCB) in the equatorial Indian Ocean: Temporal trend, continental outflow and air-water exchange. Mar. Pollut. Bull. 2014;80(1-10):194-199.

109. Zhan Z, Wang J, Peng J, Xie Q, Huang Y, Gao Y. Sorption of 3,3',4,4'-tetrachlorobiphenyl by microplastics: A case study of polypropylene. Mar. Pollut. Bull. 2016;110(1):559-563.

110. Auta HS, Emenike CU, Jayanthi B, Fauziah SH. Growth kinetics and biodeterioration of polypropylene microplastics by Bacillus sp. and Rhodococcus sp. isolated from mangrove sediment. Mar. Pollut. Bull. 2018;127:15-21.

111. Reddy MM, Deighton M, Gupta RK, Bhattarchaya SN, Parthasarathy R. Biodegradation of oxo-biodegradable polyethylene. J. Appl. Polym. Sci. 2008;111(3):1426-1432.
112. Smith M, Love DC, Rochman CM, Neff RA. Microplastics in Seafood and the Implications for Human Health. Curr. Envirion. Health Rpt. 2018;5:375-386.

113. Priyanka N, Archana T. Biodegradability of Polythene and Plastic By The Help of Microorganism: A Way for Brighter Future. J. Environ. Anal. Toxicol. 2011;1:4.

114. Grima S, Bellon-Maurel V, Feuilloley P, et al. Aerobic Biodegradation of Polymers in Solid-State Conditions: A Review of Environmental and Physicochemical Parameter Settings in Laboratory Simulations. J. Polym. Environ. 2000;8:183-195.

115. Gangadoo S, Owen S, Rajapaksha P. Nano-plastics and their analytical characterisation and fate in the marine environment: From source to sea. Sci. Total Environ. 2020;732:138792.

116. Chae Y, Kim D, An Y. Effects of micro-sized polyethylene spheres on the marine microalga Dunaliella salina: Focusing on the algal cell to plastic particle size ratio. Aquat. Toxicol. 2019;216:105296.

117. Zhang C, Chen X, Wang J, Tan L. Toxic effects of microplastic on marine microalgae Skeletonema costatum: Interactions between microplastic and algae. Environ. Pollut. 2017;220: 1282-1288.

118. Zhu C, Zhai X, Xi Y, et al. Progress on the development of floating photobioreactor for microalgae cultivation and its application potential. World J. Microbiol. Biotechnol. 2019;35:190.

119. Song C, Liu Z, Wang C, Li S, Kitamura Y. Different interaction performance between microplastics and microalgae: The bio-elimination potential of Chlorella sp. L38 and Phaeodactylum tricornutum MASCC-0025. Sci. Total Environ. 2020;723:138146.

120. Long M, Paul-Pont I, Hégaret H, et al. Interactions between polystyrene microplastics and marine phytoplankton lead to species-specific hetero-aggregation. Environ. Pollut. 2017;228: 454-463.

121. Kalčíková G, Skaler T, Marolt G, Kokalj AJ. An environmental concentration of aged microplastics with adsorbed silver significantly affects aquatic organisms. Water Res. 2010;175: 115644.

122. Wang S, Chen H, Zhou X, et al. Microplastic abundance, distribution and composition in the mid-west Pacific Ocean. Environ. Pollut. 2020;264:114125.

123. Guschina IA, Hayes AJ, Ormerod SJ. Polystyrene microplastics decrease accumulation of essential fatty acids in common freshwater algae. Environ. Pollut. 2020;263:114425.

124. Nava V, Leoni, B A critical review of interactions between microplastics, microalgae and aquatic ecosystem function. Water Res. 2020;188:116476.

125. Gall SC, Thompson RC. The impact of debris on marine life. Mar. Pollut. Bull. 2015;92(1-2):170-179.

126. Lavers JL, Bond AL. Exceptional and rapid accumulation of anthropogenic debris on one of the world's most remote and pristine islands. Proc. Natl. Acad. Sci. 2017;114(23):201619818.

127. Rochman $\mathrm{C}$, Hoh E, Kurobe $\mathrm{T}$, et al. Ingested plastic transfers hazardous chemicals to fish and induces hepatic stress. Sci. Rep. 2013;3:3263.

128. Van Cawenberghe L, Janssen CR. Microplastics in bivalves 
cultured for human consumption. Environ. Pollut. 2014;193: 65-70.

129. $\mathrm{Li} \mathrm{J}, \mathrm{Qu} \mathrm{X}, \mathrm{Su} \mathrm{L}$, et al. Microplastics in mussels along the coastal waters of China. Environ. Pollut. 2016;214:177-184.

130. Kolandhasamy P, Li LS, Qu X, Jabeen K, Shi H. Adherence of microplastics to soft tissue of mussels: A novel way to uptake microplastics beyond ingestion. Sci. Total Environ. 2018;610-611:635-640.

131. Choi JS, Jung YJ, Hong NH, Hong SH, Park JW. Toxicological effects of irregularly shaped and spherical microplastics in a marine teleost, the sheep's head minnow (Cyprinodon variegatus). Mar. Pollut. Bull. 2018;29(1):231-240.

132. Espinosa C, Cuesta A, Esteban MA. Effects of dietary polyvinylchloride microparticles on general health, immune status and expression of several genes related to stress in gilthead seabream (Sparus aurata L.). Fish Shellfish Immunol. 2017;68:251-259.

133. Espinosa C, Cuesta A, Esteban MA. Dietary administration of PVC and PE microplastics produces histological damage, oxidative stress and immunoregulation in European sea bass (Dicentrarchus labrax L.). Fish Shellfish Immunol. 2019;95:574-583.

134. Romano N, Ashikin M, Teh JC, Syukri F, Kanami A. Effects of pristine polyvinyl chloride fragments on whole body histology and protease activity in silver barb Barbodes gonionotus fry. Environ. Pollut. 2019;237:1106-1111.

135. Nelms SE, Barnett J, Brownlow A, et al. Microplastics in marine mammals stranded around the British coast: ubiquitous but transitory? Sci. Rep. 2019;9:1075.

136. Nelms SE, Galloway TS, Godley BJ, et al. Investigating microplastic trophic transfer in marine. Environ. Pollut. 2018;238: 999-1007.

137. Besseling E, Foekema EM, Franekes JAV, et al. Microplastic in a macro filter feeder: Humpback whale Megaptera novaeangliae. Mar. Pollut. Bull. 2015;95(1):248-252.

138. Prata JC, Lavorante BRBO, Montenegro MCBSM, Guihermino L. Influence of microplastics on the toxicity of the pharmaceuticals procainamide and doxycycline on the marine microalgae Tetraselmis chuii. Aquat. Toxicol. 2018;197:143-152.

139. Cunha C, Faria M, Nogueira N, Ferreira A, Cordeiro N. Marine vs freshwater microalgae exopolymers as biosolutions to microplastics pollution. Environ. Pollut. 2019;249:372-380.

140. Seoane M, González-Fernández C, Soudant P, et al. Polystyrene microbeads modulate the energy metabolism of the marine diatom Chaetoceros neogracile. Environ. Pollut. 2019;251: 363-371.

141. Prata JC, da Costa JP, Lopes I, Duarte AC, Rocha-Santos T. Effects of microplastics on microalgae populations: A critical review. Sci. Total Environ. 2019;665:400-405.

142. Garrido S, Linares M, Campillo JA, Albentosa M. Effect of microplastics on the toxicity of chlorpyrifos to the microalgae Isochrysis galbana, clone t-ISO. Ecotoxicol. Environ. Saf. 2019;173:103-109.

143. Lin L, Tang S, Wang X, Sun X, Yu A. Adsorption of malachite green from aqueous solution by nylon microplastics: Reaction mechanism and the optimum conditions by response surface methodology. Process Saf. Environ. Prot. 2020;140:339-347.
144. Hoffmann L, Eggers SL, Allhusen E, Katlein C, Peeken I. Interactions between the ice algae Fragillariopsis cylindrus and microplastics in sea ice. Environ. Int. 2020;139:105697.

145. Chi J, Li Y, Gao J. Interaction between three main marine algae and two phthalate acid estersa. Ecotoxicol Environ. Saf. 2018;170:407-411.

146. Mackintosh CE, Maldonado JA, Ikonomou MG, Gobas FA. Sorption of phthalate esters and PCBs in a marine ecosystem. Environ. Sci. Technol. 2006;40:3481-3488.

147. Oliveira M, Ribeiro A, Hylland K, Guihermino L. Single and combined effects of microplastics and pyrene on juveniles $(0+$ group) of the common goby Pomatoschistus microps (Teleostei, Gobiidae). Ecol. Indic. 2013;34:641-647.

148. Pannetier P, Morin B, Bihanic FL, et al. Environmental samples of microplastics induce significant toxic effects in fish larvae. Environ. Int. 2020;134:105047.

149. Chen Q, Gundlach M, Yang S, et al. Quantitative investigation of the mechanisms of microplastics and nanoplastics toward zebrafish larvae locomotor activity. Sci. Total Environ. 2017;584-585:1022-103.

150. Barboza LGA, Vieira LR, Guilhermino L. Single and combined effects of microplastics and mercury on juveniles of the European seabass (Dicentrarchus labrax): Changes in behavioural responses and reduction of swimming velocity and resistance time. Environ. Pollut. 2018;236:1014-1019.

151. Lin $\mathrm{W}$, Jiang $\mathrm{R}, \mathrm{Hu} \mathrm{S}$, et al. Investigating the toxicities of different functionalized polystyrene nanoplastics on Daphnia magna. Ecotoxicol. Environ. Saf. 2019;180:509-516.

152. Jensen LH, Motti CA, Garm AL, et al. Sources, distribution and fate of microfibres on the Great Barrier Reef, Australia. Sci Rep. 2019;9:9021.

153. Cheryl H, Allyn D, Kathryn D. Scleractinian coral microplastic ingestion: potential calcification effects, size limits, and retention. Mar. Pollut. Bull. 2018;135:587-593.

154. Jessica R, Schellenberg J, Schubert P, Wilke T. Responses of reef building corals to microplastic exposure. Environ. Pollut. 2018;237:955-960.

155. Hermabessiere L, Dehaut A, Paul Pont I, et al. Occurrence and effects of plastic additives on marine environments and organisms: A review. Chemosphere 2017;182:781-793.

156. Fossi MC, Coppola D, Baini M, et al. Large filter feeding marine organisms as indicators of microplastic in the pelagic environment: The case studies of the Mediterranean basking shark (Cetorhinus maximus) and fin whale (Balaenoptera physalus). Mar. Environ. Res. 2014;100:17-24.

157. Tanaka K, Takada H, Yamashita R, Mizukawa K, Fukuwaka M, Watanuli Y. Facilitated Leaching of Additive-Derived PBDEs from Plastic by Seabirds' Stomach Oil and Accumulation in Tissues. Environ. Sci. Technol. 2015;49(19): 11799-11807.

158. RomeoT, Pietro B, Peda C, Consoli P, Andaloro F, Fossi MC. First evidence of presence of plastic debris in stomach of large pelagic fish in the Mediterranean Sea. Mar. Pollut. Bull. 2015;95(1):358-361.

159. Gallo F, Fossi C, Weber R, et al. Marine litter plastics and microplastics and their toxic chemicals components: the need for urgent preventive measures. Environ. Sci. Eur. 2018;30:13. 
160. Hardesty B, Harari S, Isobe A. Using Numerical Model Simulations to Improve the Understanding of Micro-plastic Distribution and Pathways in the Marine Environment. Front. Mar. Sci. 2017;4

161. Cutroneo L, Reboa A, Besio G. Microplastics in seawater: sampling strategies, laboratory methodologies, and identification techniques applied to port environment. Environ. Sci. Pollut. Res. Int. 2020;27(9):8938-8952.

162. Brown DM, Cheng L. New net for sampling the ocean surface. Mar. Ecol. Prog. Ser. 1981;5:225-227.

163. Lebreton L, Slat B, Ferrari F, et al. Evidence that the Great Pacific Garbage Patch is rapidly accumulating plastic. Sci. Rep. 2018;8:4666.

164. van Sebille E, England MH, Froyland G. Origin, dynamics and evolution of ocean garbage patches from observed surface drifters. Environ. Res. Lett. 2012;7(4):044040.

165. Olivelli A, Hardesty BD, Wilcox C. Coastal margins and backshores represent a major sink for marine debris: insights from a continental-scale analysis. Environ. Res. Lett. 2020;15: 074037.

166. Phelan A, Ross H, Setianto NA, Fielding K, Pradipta L. Ocean plastic crisis - Mental models of plastic pollution from remote Indonesian coastal communities. PLOS ONE. 2020;15(7): e0236149.

167. Siefried M, Koelmans AA, Besseling E, Kroeze C. Export of microplastics from land to sea. A modelling approach. Water Res. 2017;127:249-257.

168. Mai L, Sun X, Xia L, Bao L, Liu L, Zeng EY. Global riverine plastic outflows. Environ. Sci. Technol. 2020;54:10049-10056.

169. Nihei Y, Yoshida T, Kataoka Ogata R. High resolution mapping of Japanese microplastic and microplastic emission from the land in to sea. Water 2020;12:951.

170. Whitehead PG, Bussi G, Hughes JMR, et al. Modelling Microplastics in the River Thames: Sources, Sinks and Policy Implications. Water 2021;13:861.

171. Liu J, Zhang T, Tian L, et al. Aging Significantly Affects Mobility and Contaminant-Mobilizing Ability of Nanoplastics in Saturated Loamy Sand. Environ. Sci. Technol. 2019;53(10): 5805-5815.

172. Chaturvedi S, Yadav BP, Siddiqui NA, Chaturvedi SK. Mathematical modelling and analysis of plastic waste pollution and its impact on the ocean surface. JOES. 2020;5(2): 136-163.

173. Seitzinger SP, Mayorga E, Bouwman AF, et al. Global river nutrient export: A scenario analysis of past and future trends. Global Biogeochem. Cycles. 2010;24(4):1-6.

174. Mayorga E, Seitzinger SP, Harrison JA, et al. Global Nutrient Export from Water Sheds 2 (NEWS 2): Model development and implementation. Environ. Model Softw. 2010;25(7)837-853.

175. Everaert G, Cauwenberghe LV, Rijcke MD, et al. Risk assessment of microplastics in the ocean: Modelling approach and first conclusions. Environ. Pollut. 2018;242(Part B):1930-1938.

176. Report for the European Commission DG Environment. Study to support the development of measures to combat a range of marine litter sources [Internet]. Sherrington C, Darrah C, Hann S, Cole G, Corbin M; 2016 [cited 10 December 2020]. Available from: https:/ec.europa.eu/environment/marine/ good-environmental-status/descriptor-10/pdf/MSFD\% 20Measures\% 20to\%20Combat\%20Marine\%20Litter.pdf.

177. Cózar A, Echevarría F, González-Gordillo JI, et al. Plastic debris in the open ocean. Proc. Natl. Acad. Sci. 2014;111(8): 10239-10244.

178. Eriksen M, Lebreton LCM, Carson HS, et al. Plastic Pollution in the World's Oceans: More than 5 Trillion Plastic Pieces Weighing over 250,000 Tons Afloat at Sea. PLOS ONE. 2014;9(12):e111913.

179. Isobe A, Uchida K, Tokai T, Iwasaki S. East Asian seas: A hot spot of pelagic microplastics. Mar. Pollut. Bull. 2015;101 (2):618-623.

180. Kako S, Isobe A, Kubota M. High-resolution ASCAT wind vector data set gridded by applying an optimum interpolation method to the global ocean. J. Geophys. Res. Atmos. 2011;116(D23):15484.

181. Kako S, Morita S, Taneda T. Estimation of plastic marine debris volumes on beaches using unmanned aerial vehicles and image processing based on deep learning. Mar. Pollut. Bull. 2020;155:111127.

182. Mountford AS, Maqueda MAM. Eulerian Modeling of the Three-Dimensional Distribution of Seven Popular Microplastic Types in the Global Ocean. J. Geophys. Res. Oceans. 2019;124(12):8558-8573.

183. Mai L, You S, Bao L, Liu L, Zeng EY. Riverine Microplastic Pollution in the Pearl River Delta, China: Are Modeled Estimates Accurate? Environ. Sci. Technol. 2019;53(20): 11810-11817.

184. Koelmans AA, Besseling E, Wegner A, Foekema EM. Plastic as a Carrier of POPs to Aquatic Organisms: A Model Analysis. Environ. Sci. Technol. 2013;47(14):7812-7820.

185. Stamataki N, Hatzonikolakis Y, Tsiaras K, et al. Modelling mussel (Mytilus spp.) microplastic accumulation. Ocean Sci. 2020;16:927-949.

186. Fernandez B, Albentosa M. Dynamic of small polyethylene microplastics $(\leq 10 \mu \mathrm{m})$ in mussel's tissues. Mar. Pollut. Bull. 2019;146:493-501.

187. Granby K, Rainieri S, Rasmussen R, et al. The influence of microplastics and halogenated contaminants in feed on toxicokinetics and gene expression in European seabass (Dicentrarchus labrax). Environ. Res. 2018;164:430-443.

188. Pirsaheb M, Hossini H, Makhdoumi P. Review of microplastic occurrence and toxicological effects in marine environment: Experimental evidence of inflammation. Process Saf. Environ. Prot. 2020;142:1-14. 